\title{
СКЛАДНІ ЕПОНІМИ УКРАЇНСЬКОЇ ФІЗИЧНОЇ ТЕРМІНОЛОГІЇ
}

\author{
РОМАН МИКУЛЬЧИК \\ Національний університет „Львівська політехніка”, Львів - Україна

\section{ZŁOŻONE EPONIMY UKRAIŃSKIEJ TERMINOLOGIJI FIZYCZNEJ}

ROMAN MYKULCZYK

Narodowy Uniwersytet „Politechnika Lwowska”, Lwów — Ukraina

STRESZCZENIE. Artykuł poświęcony jest złożonym terminom - eponimom ukraińskiej terminologii fizycznej. Przeanalizowano kwestię zgodności elementów złożonych eponimów oraz główne metody tworzenia tych terminów.

\section{COMPLEX EPONYMS OF UKRAINIAN PHYSICAL TERMINOLOGY}

\author{
ROMAN MYKULCHYK \\ National University “Lviv Polytechnic”, Lviv — Ukraine
}

ABSTRACT. The article is devoted to the complex eponymic terms of Ukrainian physical terminology. The question of the compatibility of complex eponymic terms components and the main methods of these terms forming are considered.

$\mathrm{E}$ понім - це назва, утворена від імені чи прізвища особи. Найменування 3 компонентами-власними назвами, зокрема у функції термінів, давно привертали увагу дослідників. Вивчали цю проблему Д. Лотте ${ }^{1}$, В. Болотов ${ }^{2}$, О. Суперанська ${ }^{3}$ Ю. Карпенко ${ }^{4}$, Б. Михайлишин ${ }^{5}$, М. Дзюба ${ }^{6}$ та ін. Дослідження в галузі термінознавства доводять, що головною умовою творення термінів-відантропонімів $є$ наявність історичної згадки про існування тих чи тих осіб, чиї імена лежать в основі творення епонімів.

Мета статті - дослідити складні епонімні терміни української фізичної лексики, виділити семантичні групи цих термінів, описати способи творення складних епонімів. Складні епоніми - це терміни, що у своєму складі мають епонім і ще хоча б один терміноелемент, напр.: ампер + метр, вольт + метр, кіло + джоуль, гіга + паскаль тощо. Дослідимо сполучуваність відпрізвищевих компонентів із додатковими компонентами для цих термінів. Характерною будемо вважати словотвірну сполучуваність епонімного компонента 3 міжнародним терміноелементом, причому міжнародні терміноелементи можуть бути

1 Д. С. Лотте, Некоторые приниипиальные вопросы отбора и построения научнотехнических терминов, Москва-Ленинград 1941.

${ }^{2}$ В. И. Болотов, Значение слова, термина и энциклопедическое значение имени собсвенного, [в:] Вопросы разработки научно-технической терминологии, Рига 1973, с. 103-114.

${ }^{3}$ А. В. Суперанская, Типы и структура географических названий, [в:] Лингвистическая терминология и прикладная топ ономастика, Москва 1984, с. 59-118.

${ }^{4}$ Ю. О. Карпенко, Творення загальних назв від власних, [в:] „Українська мова і література в школі” 1973, № 10. с. 23-30.

${ }^{5}$ Б. П. М и х а й л и ш и н , 3 історії термінів-епонімів, [в:] „Мовознавство”, 1994, № 45, с. 45-50.

${ }^{6}$ М. М. Дз юб а Епоніми в українській науковій термінології, Луцьк 2011. 
як непрізвищевими (кіловольт, децибел, мегапаскаль, вольтміліамперметр, вольтоскоп тощо), так і прізвищевими (гальванопокриття, гальваностереотипія, гальванохромія, гальванопокривання тощо).

Серед складних епонімів за значенням можна виокремити такі тематичні групи:

- кратні та частинні одиниці фізичних величин;

- прилади й пристрої;

- розділи фізики й галузі техніки.

Розгляньмо ці семантичні групи. Кратні та частинні одиниці фізичних величин - це терміни, утворені префіксальним способом від основних системних одиниць фізичних величин. Так утворюються терміни на позначення кратних та частинних одиниць фізичних величин, кратні десяти. У таблиці 1 подамо міжнародні терміноелементи-префікси, що слугують для утворення десяткових кратних і частинних одиниць.

Таблиия 1

Префікси СІ та множники для утворення

десяткових кратних і частинних одинищь

\begin{tabular}{|c|c|c|c|c|c|}
\hline \multicolumn{5}{|c|}{ Префікси СІ } \\
\hline \multicolumn{3}{|c|}{ Кратні одиниці } & \multicolumn{3}{|c|}{ Частинні одиниці } \\
\hline Множник & Назва & Позначення & Множник & Назва & Позначення \\
\hline $10^{1}$ & дека- & Дк & $10^{-1}$ & деци & Д \\
\hline $10^{2}$ & гекто- & $\Gamma$ & $10^{-2}$ & санти & С \\
\hline $10^{3}$ & кіло- & К & $10^{-3}$ & Мілі & М \\
\hline $10^{6}$ & мега- & М & $10^{-6}$ & мікро & Мк \\
\hline $10^{9}$ & гіга- & Г & $10^{-9}$ & нано & Н \\
\hline $10^{12}$ & тера- & Т & $10^{-12}$ & Піко & П \\
\hline $10^{15}$ & пета- & П & $10^{-15}$ & фемто & Ф \\
\hline $10^{18}$ & екса- & Е & $10^{-18}$ & Ато & А \\
\hline $10^{21}$ & зета- & 3 & $10^{-21}$ & зетто & 3 \\
\hline $10^{24}$ & йота- & $\breve{~ И ~}$ & $10^{-24}$ & йокто & Й \\
\hline
\end{tabular}

Основні правила правопису одиниць уведено 6-ою Генеральною конвенцією 3 мір та ваг 1948 р. Сьогодні існує загальна міжнародна згода щодо написання та використання позначень і назв одиниць виміру та префіксів. Дотримання правил сприяє підвищенню читабельності текстів: а) якщо одиницю виміру названо на честь людини, то перша буква позначення $є$ завжди великою, але повну назву пишуть 3 малої літери, напр.: $2 \mathrm{H}$, але 2 ньютони; 200 мкФ, але 200 мікрофарад; б) якщо використовують префікси, то вони передують базовій одиниці, пишуться разом й утворюють 3 нею нерозривні слова, напр. ме- 
гават; в) позначення кратних префіксів, крім гекто-, дека-, кіло-, пишуть $з$ великої літери, позначення всіх частинних префіксів завжди пишуть 3 малої букви; г) заборонено використовувати складені префікси. Використання двох або більше префіксів поспіль також не дозволено, напр.: 10-9 фарад слід позначати нанофарад, а не мікроміліфарад. Для прикладу, наведемо таблиці сполучуваності деяких епонімів - назв фізичних величин із міжнародними терміноелементами-префіксоїдами, що позначають кратність та частинність. Приклади подаємо для терміна ньютон.

Таблиия 2

Десяткові кратні й частинні одиниці, утворені за допомогою стандартних префіксів СI

\begin{tabular}{|c|c|c|c|c|c|c|c|}
\hline \multicolumn{4}{|c|}{ Кратні } & \multicolumn{4}{|c|}{ Частинні } \\
\hline Величина & Назва & Позн & тення & Величина & Назва & Позн & ення \\
\hline $10^{1} \mathrm{H}$ & деканьютон & ДаН & $\mathrm{daN}$ & $10^{-1} \mathrm{H}$ & дециньютон & дН & $\mathrm{dN}$ \\
\hline $10^{2} \mathrm{H}$ & гектоньютон & $\Gamma_{\mathrm{H}}$ & $\mathrm{hN}$ & $10^{-2} \mathrm{H}$ & сантиньютон & $\mathrm{cH}$ & $\mathrm{cN}$ \\
\hline $10^{3} \mathrm{H}$ & кілоньютон & $\mathrm{K}_{\mathrm{H}}$ & $\mathrm{kN}$ & $10^{-3} \mathrm{H}$ & міліньютон & $\mathrm{MH}$ & $\mathrm{mN}$ \\
\hline $10^{6} \mathrm{H}$ & меганьютон & $\mathrm{MH}$ & $\mathrm{MN}$ & $10^{-6} \mathrm{H}$ & мікроньютон & мкH & $\mu \mathrm{N}$ \\
\hline $10^{9} \mathrm{H}$ & гіганьютон & $\Gamma \mathrm{H}$ & GN & $10^{-9} \mathrm{H}$ & наноньютон & $\mathrm{HH}$ & $\mathrm{nN}$ \\
\hline $10^{12} \mathrm{H}$ & тераньютон & $\mathrm{TH}$ & $\mathrm{TN}$ & $10^{-12} \mathrm{H}$ & піконьютон & пH & $\mathrm{pN}$ \\
\hline $10^{15} \mathrm{H}$ & петаньютон & $\Pi \mathrm{H}$ & $\mathrm{PN}$ & $10^{-15} \mathrm{H}$ & фемтоньютон & $\phi H$ & $\mathrm{fN}$ \\
\hline $10^{18} \mathrm{H}$ & ексаньютон & $\mathrm{EH}$ & $\mathrm{EN}$ & $10^{-18} \mathrm{H}$ & атоньютон & $\mathrm{aH}$ & $\mathrm{aN}$ \\
\hline $10^{21} \mathrm{H}$ & зетаньютон & $3 \mathrm{H}$ & $\mathrm{ZN}$ & $10^{-21} \mathrm{H}$ & зептоньютон & $3 \mathrm{H}$ & $\mathrm{zN}$ \\
\hline $10^{24} \mathrm{H}$ & йотаньютон & $\breve{И ̆}$ & $\mathrm{YN}$ & $10^{-24} \mathrm{H}$ & йоктоньютон & йН & $\mathrm{yN}$ \\
\hline
\end{tabular}

Застосовувати не рекомендовано.

Назви позасистемних одиниць фізичних величин (напр., антстрем, зіверт, сименс, ерстед) не утворюють кратних і частинних одиниць; відповідно, вони не сполучаються з міжнародними терміноелементами-префіксоїдами на позначення кратності / частинності.

Назви вимірювальних приладів. Міжнародних терміноелементів тут два: -метр - 8 термінів (амперметр, вольтметр, гальванометр, омметр, вольтміліамперметр, гаусметр, джоулометр, вольтомметр); -скоп - 2 терміни (вольmоскоп, гальваноскоп). За частотністю поєднання однозначно переважає суфіксоїд -метр (80 \% термінів вибірки містять цей компонент), оскільки терміни 3 компонентом -скоп позначають прилади для спостереження явища, напр., гальваноскоп — „найпростіший прилад для виявлення сталого електричного струму в колі і визначення його напряму ${ }^{7 \prime}$, а терміни з компонентом -метр позначають вимірювальні прилади, напр., амперметр - „прилад, яким вимірюють силу електричного струму" . Приладів для спостереження значно менше, ніж вимірювальних приладів.

Існує випадок, коли обидва компоненти складного епоніма - міжнародні терміноелементи, напр.: гальваноскоп, амперметр, вольтметр тощо. Прізвищевий компонент гальван(о) є міжнародним терміноелементом, що вказує

${ }^{7}$ Великий тлумачний словник сучасної украӥнської мови, уклад. і гол. ред. В. Т. Бус ел, КиївІрпінь 2001, с. 172.

${ }^{8}$ Там само, с. 16. 
не на прізвище італійського фізика, а на малі значення сили струму, а терміноелемент (суфіксоїд) -скоп входить до складу назв приладів чи пристроїв для спостереження. Подібно і з термінами на зразок амперметр, вольтметр, джоулометр, де прізвищевий компонент указує на царину застосування приладу ( $a$ nер - сила електричного струму, вольт - електрична напруга), а міжнародний терміноелемент - суфіксоїд -метр входить у назву приладів, призначених для вимірювання, серед яких за словотвірною похідністю виділяємо такі групи: a) ті, у яких епонім є стрижневим компонентом, напр.:

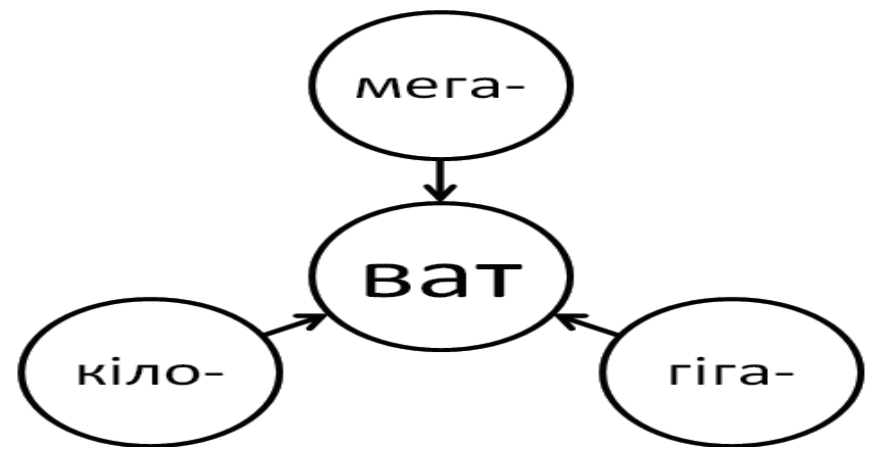

б) ті, у яких епонім є залежним компонентом, напр.:

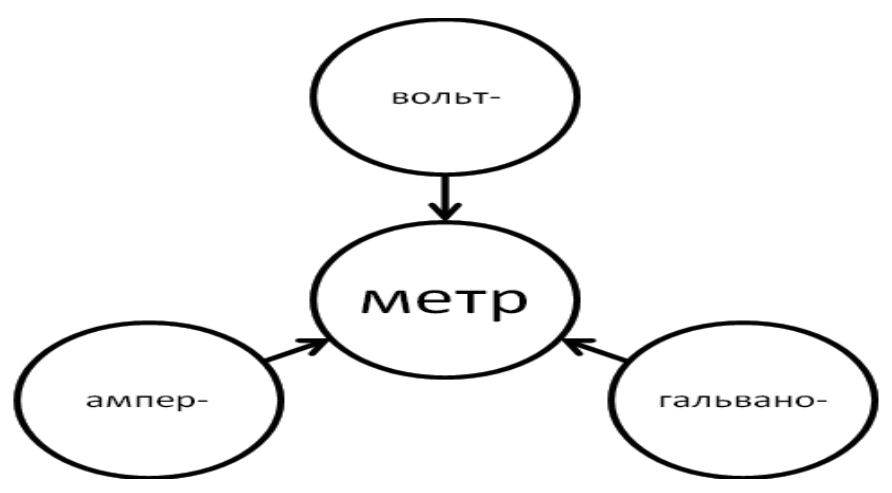

У другому випадку стрижневими є компоненти -метр, -скоп чи слова техніка, пластика, кліше тощо. Компоненти -метр, -скоп називають міжнародними терміноелементами-суфіксоїдами. Складні епоніми, крім префіксального і суфіксального способів, утворюються й префіксально-суфіксальним за схемою: міжнародний терміноелемент-префіксоїд + епонім + міжнародний терміноелемент-суфіксоїд (напр. міліамперметр).

Частина складених епонімних термінів утворюється за участю міжнародних терміноелементів-інтерфіксів за схемою: епонім + міжнародний терміноелемент-інтерфікс + епонім + міжнародний терміноелемент-суфіксоїд (напр. вольmміліамперметр). До складу таких термінів входять прізвищеві компоненти. Цей спосіб творення епонімів малопоширений. Малопоширеною є й така схема: епонім + епонім + міжнародний терміноелемент-суфіксоїд (напр. вольтамперметр).

Отже, для складних епонімів характерна наявність міжнародних терміноелементів: найчисельніші епоніми 3 міжнародними терміноелементами, що позначають степінь числа, та назви вимірювальних приладів 3 компонентами -метр і -скоп. Усі інші складні епоніми об'єднані за відпрізвищевим компонентом тальван(о), що одночасно є й міжнародним терміноелементом. 